\title{
Methods and tools for the development of a Product-Service System: a holistic perspective
}

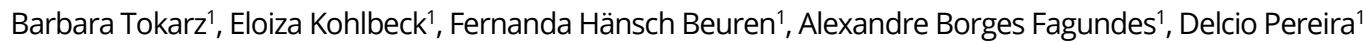

${ }^{1}$ State University of Santa Catarina - UDESC, São Bento do Sul, Brazil.

How to cite: Tokarz, B., Kohlbeck, E., Beuren, F.H. et al. (2022), "Methods and tools for the development of a Product-Service System: a holistic perspective", Brazilian Journal of Operations \& Production Management, Vol. 19, No. 3, e20221227. https://doi.org/10.14488/BJOPM.2021.046

\begin{abstract}
Goal: Present a holistic perspective of methods and tools for the development of Product Service Systems (PSS).

Design / Methodology / Approach: The investigation was conducted in two phases. The first phase presents bibliographic and bibliometric analyses, where 132 papers were read in full. In the second stage, of conceptual development, bibliographic data was grouped and validated by PSS specialists through a questionnaire, whose responses were used to conceptualize a model for PSS development.

Results: Elaboration of a concept of a model for the development of Product-Service Systems, capable of providing guidance for all stages of its life cycle.

Limitations of the investigation: The proposed model was applied to the bike sharing business model. However, a limitation was the lack of some information regarding this case to apply some methods and tools proposed in the conceptual model.

Practical implications: The model developed can be used as a guideline for the elaboration or improvement of a PSS proposal, since it provides structure and control to the business models.

Originality / Value: The paper demonstrates its originality and relevance by presenting a model centered on a holistic approach, as it provides a perspective of the whole PSS life cycle. Thus, processes are planned and analyzed from the definition of requirements to the destination after use of the PSS.
\end{abstract}

Keywords: Product-service System; Conceptual Model; Life Cycle; Methods and Tools.

\section{INTRODUCTION}

Product-Service Systems (PSS) are defined as integrated systems of products, services, network of actors and infrastructures, which aim to generate value and satisfy customers' needs (Goedkoop et al., 1999). The implementation of a PSS can bring several benefits to business propositions, such as increased competitiveness (Tukker, 2015) and improved socioeconomic performance (Baldassarre et al., 2020). However, to ensure the sustainability of PSS business proposals, it is essential to adopt a systemic perspective (França et al., 2017), considering the entire life cycle of products and services. Beuren et al. (2017) corroborate this assertion by proposing a conceptual model for the characterization of a ProductService System based on its life cycle, comprising the stages of requirements definition, development, implementation, monitoring, and destination after use.

Several PSS solutions have been discussed in the literature. One example is the Bicycle Sharing System (BSS) (Beuren et al., 2017), representing a "green" transportation mode (Zhang et al., 2015), since BSS's reduced environmental footprint is one of the reasons for its rapid growth in popularity (Bonilla-Alicea et al., 2020). However, PSS business proposals need a holistic perspective, in which the

Financial support: None.

Conflict of interest: The authors have no conflict of interest to declare.

Corresponding author: eloiza.kohlbeck@edu.udesc.br

Received: 01 May 2021

Approved: 6 Sept 2021.

Editor: Julio Vieira Neto. 
use of methods and tools contribute to the fulfillment of the requirements of a Product-Service System (Beuren et al., 2013).

As for the development of conceptual models and the use of methods and tools to support PSS proposals, Frederiksen et al. (2021) present an approach composed of a method and a tool to assist in the early stages of development of new PSS business models, applying the approach in a Danish manufacturing company. Furthermore, Sakao et al. (2020) propose a model, a method, and a tool, which support the conceptual design of PSS proposals. First, a PSS family model is presented and implemented as a complement to the Computer-Aided Design (CAD) tool. Next, a method based on the model and lean manufacturing is developed. Thus, the proposed model, method, and tool were shown to be effective in describing key elements of PSS design (Sakao et al., 2020).

It is observed that the literature does not present a comprehensive view of the entire ProductService Systems life cycle, as methods and tools are proposed only for some stages of the cycle, usually the early ones. Moreover, PSS is still adopted in a limited way (van der Laan and Aurisicchio, 2020), and there are few works in the literature that present its full development process (Kim and Lee, 2020). A possible reason for this limitation in PSS development is that models, methods, and tools (Tokarz et al., 2020) that help meet customer needs (Pezzotta et al., 2015) do not provide practical guidance to industry practitioners (Tran and Park, 2016a).

Therefore, it is essential to investigate the development of approaches that can satisfy the requirements of a PSS (Beuren et al., 2013) and adapt them to different scenarios considering the entire Product-Service System life cycle (Matsas et al., 2017). In view of this, the goal of this paper is to present a holistic perspective of methods and tools for the development of Product Service Systems.

\section{RESEARCH METHODS}

The research was conducted in two main phases, as presented in Figure 1. The first phase conducted a literature review in order to define the research goal, through bibliometric and bibliographic analysis, which allowed to rescue collective insights based on the theoretical synthesis of existing studies (Reim et al., 2015). The second phase was conducted with the aim of proposing the concept of a model for PSS development, based on its entire life cycle. Aiming at validating the model, a questionnaire was applied with PSS specialists, and their responses were used for feedback on the model.

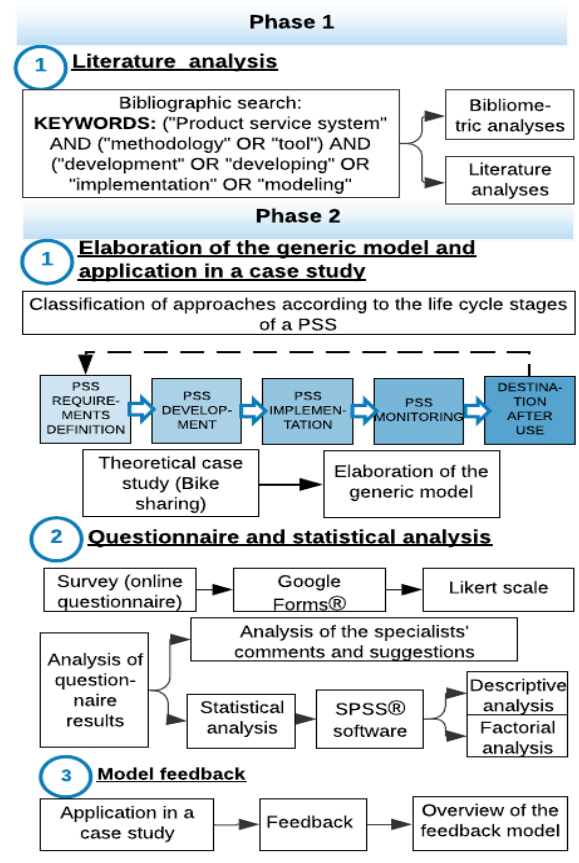

Figure 1. Research methods.

Source: Authors. 


\section{Phase 1 of the research: literature analysis}

A bibliographic search was initially conducted in Scopus and Web of Science databases (Chadegani et al., 2013). The keywords displayed in Figure 1 were searched as topics on papers, limiting the search to articles from 2008 to 2017. The search encountered 196 nonduplicated files.

As bibliometric analyses allow objective studies of literature and the comprehension of intellectual foundations, they emerged as a technique to assist directing the research. Cocitation of references, specifically, connect documents and reflect the state of the field, congregating researches considered relevant by those who publish on the subject (Zupic and Čater, 2015).

Therefore, a co-citation of references analysis was performed in VOSviewer ${ }^{\circledR}$ software. The software only allows analysis from one database, so Scopus was chosen as it gathered more papers when compared to Web of Science. The analysis was performed with 183 articles and 8097 references. With a minimum number of eight citations of a reference, 12 researches were found to meet the parameters. The bibliometric results presented an opportunity to conceptualize a model for PSS development, which was also expressed as a gap by Cavalieri and Pezzotta (2012) and Tran and Park (2016b).

The title, abstract, and keywords of the 196 researches found in the literature search were read, and 87 articles were selected to be read in full. This sample formed the basis for the development of a conceptual model, allowing the identification of methods and tools (Pezzotta et al., 2015), which were gathered in tables and are presented in the results section.

\section{Phase 2 of the research}

\section{Conceptual development and application in a case study}

Through phase 1, methods and tools related to the development of product-service systems were identified in literature and classified according to the stages of the PSS lifecycle they referred to and the number of citations in the literature. For the elaboration of the conceptual model, methods and tools cited seven or more times were considered, and thus 12 were selected. Although some are used in more than one phase of the cycle, their contributions are distinct for each step.

To analyze the proposal's feasibility, it was tested in a theoretical case study. The methods and tools presented were employed in a bike sharing business proposal (use oriented PSS), resulting in improvements in the model to make it more appropriate for the development of product-service systems. With the case study application, a model for PSS development was conceptualized.

\section{Questionnaire and statistical analysis}

The questionnaire used in the survey to analyze the concept's feasibility (Labbate et al., 2021) was prepared through Google Forms ${ }^{\circledR}$ (Chandra et al., 2019). In order to analyze the influence of the methods and tools on the phases of the PSS lifecycle, we selected a semantic Likert scale with five gradations. Likert scales are easy to apply and facilitate the arrangement of respondents' answers, increasing efficiency in data collection (Chen and Yu, 2020).

To ensure greater credibility of the data obtained from the questionnaire, opinions of specialists in Product-Service Systems were considered. ORCID (Open Researcher and Contributor ID) and Lattes Curriculum platforms were used to select 200 specialists.

Data obtained through the questionnaire (with a return response of 20.5\%), was analyzed through the Statistical Package for the Social Scienses ${ }^{\circledR}$ (SPSS) software. SPSS is a complete and widely employed statistical software (Qi et al., 2020), and for this study, the descriptive and factorial analysis of data were listed.

To verify if the data was adequate for the factor analysis, the Kaiser-Meyer-Olkin (KMO) test was performed and the Cronbach alpha coefficient was analyzed. The KMO test analyzes 
the accuracy and strength of factor analysis (Karabagias et al., 2020). Results above 0.7 are considered satisfactory (Fadheel et al., 2018). Cronbach's alpha coefficient is used to check the level of data consistency (Yaduvanshi et al., 2019) and the reliability of the measurement instrument (Durán and Condorí, 2019). Its results should also be above 0.7, indicating statistical significance (Coşkun et al., 2019).

\section{Model feedback}

With the information obtained through opinions and suggestions of the specialists and statistical analyses, the conceptual model was retro-fed with the aim of making it more appropriate for the development of product-service systems. A new application in the theoretical case study was conducted to analyze the feasibility of the methods and tools included in the model.

The model was synthetized considering the phases of the PSS lifecycle, represented as A, $B, C, D$ and $E$ (Table 1). Methods and tools are identified with the letter corresponding to each lifecycle stage in Table 1 and numbered sequentially, following the example of phase A: definition of requirements. The methods and tools of this life cycle phase are represented as: $A 1, A 2, \ldots A 11$, and their contributions are used in stage $B$, development of a PSS.

The Failure Mode and Effect Analysis (FMEA) method was adopted in the conceptual model as a tool gate, employed between the lifecycle phases. According to Rozenfeld et al. (2006) the stage gate approach consists of a set of phases and decision points that represent a development process.

The number of methods and tools initially gathered for the model (phase 1), those added, those excluded (based on specialist opinion and statistical analysis), and finally shown in the feedback model (phase 2), are presented in Table 1.

Table 1. Methods and tools.

\begin{tabular}{|c|c|c|c|c|c|}
\hline Index & Lifecycle phase & $\begin{array}{c}\text { Initial } \\
\text { (phase 1) }\end{array}$ & Added & Excluded & $\begin{array}{c}\text { Final } \\
\text { (phase 2) }\end{array}$ \\
\hline A & $\begin{array}{l}\text { PSS Requirements } \\
\text { Definition }\end{array}$ & 8 & 6 & 3 & 11 \\
\hline B & PSS Development & 8 & 3 & 3 & 8 \\
\hline C & PSS Implementation & 7 & 3 & 3 & 7 \\
\hline D & PSS Monitoring & 5 & 3 & 4 & 4 \\
\hline $\mathrm{E}$ & $\begin{array}{c}\text { PSS Destination After } \\
\text { Use }\end{array}$ & 6 & 1 & 4 & 3 \\
\hline
\end{tabular}

Source: Authors.

\section{RESULTS AND DISCUSSIONS}

\section{Results and discussions from phase 1}

Figure 2 shows the reference co-citation network, formed by 12 nodes - the papers that met the defined parameters (step described in the methodology - Phase 1 of the research). It is important to point out that we were not able to edit the source document for VOSviewer ${ }^{\circledR}$, so the research of Mont (2002) shows up in both clusters in Figure 2. 


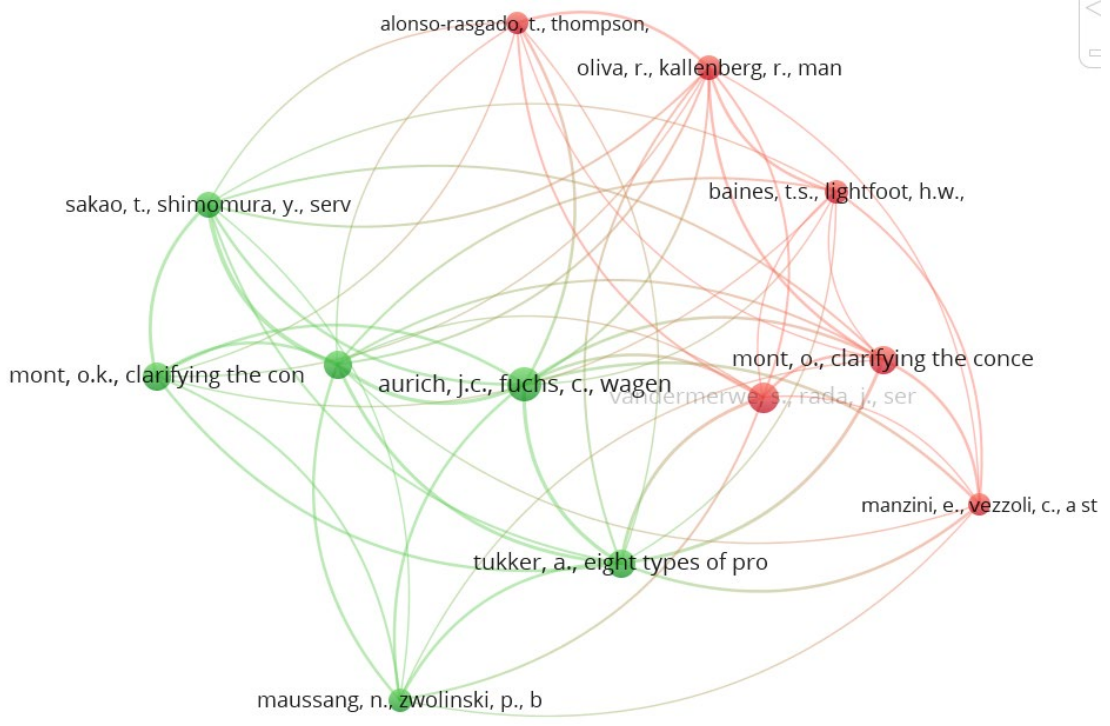

Figure 2. Co-citation of references network. Source: Authors.

The most relevant papers of Cluster A (red) and Cluster B (green) were gathered on Table 2. These are the papers with the strongest citation links in the network. Works in both clusters are some of the first researches on the PSS subject.

Table 2. Clustering for co-citation of references.

\begin{tabular}{|c|c|c|c|}
\hline Cluster & Reference & Article & Link strength \\
\hline \multirow{3}{*}{ A } & (Mont, 2002) & Clarifying the concept of product-service system & 23 \\
\hline & $\begin{array}{l}\text { (Oliva and Kallenberg, } \\
\text { 2003) }\end{array}$ & Managing the transition from products to services & 21 \\
\hline & $\begin{array}{l}\text { (Vandermerwe and } \\
\text { Rada, 1988) }\end{array}$ & Servitization of business: adding value by adding services & 19 \\
\hline \multirow{3}{*}{ B } & (Aurich et al., 2006) & $\begin{array}{l}\text { Lifecycle oriented design of technical Product-Service } \\
\text { Systems }\end{array}$ & 36 \\
\hline & (Tukker, 2004) & $\begin{array}{l}\text { Eight types of product-service system: Eight ways to } \\
\text { sustainability? Experiences from SusProNet }\end{array}$ & 32 \\
\hline & (Morelli, 2006) & $\begin{array}{l}\text { Developing new product service systems (PSS): } \\
\text { methodologies and operational tools }\end{array}$ & 31 \\
\hline
\end{tabular}

Source: Authors.

Researches in cluster A are Introductions to Servitization. The researches here comprehended express the importance of servitizing a business model. Vandermerwe and Rada (1988) present the concept of servitization, describing customers' desires as drivers to the process and indicating the competitive benefit of integrating services in product offers. Oliva and Kallenberg (2003) study companies' transition from product to product-service offers, highlighting necessary organizational changes. Mont (2002) explores the concept of product-service systems, linking it to servitization and functional economy. Benefits to companies, consumers and the environment are presented, as are initial challenges businesses could encounter.

Cluster B is an Introduction to PSS Development. Tukker (2004) explores existing types of PSS, discusses environmental and economic characteristics of each, and presents challenges and directions to implement a PSS. Aurich et al. (2006) explore the modelling of productoriented services, focusing on planning the development. Morelli (2006) proposes some tools to be employed on PSS development, concentrated on actors' responsibilities. The author declares that the work "is only the very first step to support a PSS design process".

These are important studies on the PSS field, which were carried out throughout the years in researches such as Baines et al. (2007), Beuren et al. (2013), and Tran and Park (2016b). The theme 
discussed in Cluster B was presented in several other researches (e.g. Geum and Park, 2011; Trevisan and Brissaud, 2016; Haber and Fargnoli, 2017). While authors (Pezzotta et al., 2015) express the importance of organizational changes, customer driven processes and "suitable models, methods and tools" to be employed in PSS development, others (Tran and Park, 2016a) manifest the lack of practical models to be employed by companies' on this process, especially considering the whole lifecycle of a product-service system (Aurich et al., 2006; Baines et al., 2007).

These conclusions underline an opportunity for this research. In order to propose the concept of a model for PSS development, methods and tools to assist development were gathered from literature and classified according to the PSS lifecycle stage they attended. It is interesting to develop a PSS combining different approaches (Tokarz et al., 2020), considering its entire life cycle (Beuren et al., 2013), thus facilitating strategic decision making and adaptation to an increasingly dynamic and complex labor market (Guan et al., 2017).

Besides the 87 papers read, more extensive publications were gathered from Brazilian literature. The sample included 13 doctoral dissertations and 32 master theses, resulting in the analysis of 132 researches in total. Table 3 presents a synthesis of the bibliographic information in order to suggest methods and tools to support the stages of the life cycle of a PSS. Table 3 also shows the number of citations and references to these methods and tools.

Table 3. Methods and tools for the conceptual model.

\begin{tabular}{|c|c|c|c|}
\hline Lifecycle Stage & Methods and tools & $\mathrm{n}^{\circ}$ Citations & References \\
\hline \multirow{8}{*}{$\begin{array}{l}\text { PSS Requirements } \\
\text { Definition }\end{array}$} & $\begin{array}{l}\text { Quality Function } \\
\text { Deployment (QFD) }\end{array}$ & 21 & $\begin{array}{c}\text { (Morelli, 2009; Ribeiro, 2011; Cavalieri and } \\
\text { Pezzotta, 2012; Mazo, 2012; Yoon, Kim and } \\
\text { Rhee, 2012; Pezzotta et al., 2016; Haber and } \\
\text { Fargnoli, 2017) }\end{array}$ \\
\hline & Service Blueprint & 21 & $\begin{array}{l}\text { (Magnago, 2011; Ribeiro, 2011; Geum and } \\
\text { Park, 2011; Lim et al., 2012; Kim et al., 2015; } \\
\text { Haber and Fargnoli, 2017) }\end{array}$ \\
\hline & $\begin{array}{l}\text { Business Model } \\
\text { Canvas }\end{array}$ & 14 & $\begin{array}{c}\text { (França et al., 2017; Haber and Fargnoli, 2017; } \\
\text { Fukushima, 2018) }\end{array}$ \\
\hline & IDEFO & 13 & $\begin{array}{c}\text { (Morelli, 2009; Durugbo et al., 2011; } \\
\text { Kim et al., 2015) }\end{array}$ \\
\hline & SWOT Analysis & 12 & $\begin{array}{c}\text { (Beuren, 2011; Magnago, 2011; Costa Junior, } \\
\text { 2012; Hoss, 2014; Alvarenga Netto, 2015; } \\
\text { Fukushima, 2018) }\end{array}$ \\
\hline & Brainstorming & 11 & (Hoss, 2014; Jorge, 2017) \\
\hline & Storyboard & 10 & $\begin{array}{l}\text { (Beuren, 2011; Kim et al., 2015; Fukushima, } \\
\text { 2018) }\end{array}$ \\
\hline & FMEA & 7 & (Haber and Fargnoli, 2017) \\
\hline \multirow{8}{*}{ PSS Development } & QFD & 21 & $\begin{array}{l}\text { (Magnago, 2011; Ribeiro, 2011; Costa Junior, 2012; } \\
\text { Mazo, 2012; Kim et al., 2015; Marques, 2018) }\end{array}$ \\
\hline & Service Blueprint & 21 & $\begin{array}{l}\text { (Magnago, 2011; Ribeiro, 2011; Geum and } \\
\text { Park, 2011; Costa Junior, 2012; Yoon et al., } \\
\text { 2012; Pezzotta et al., 2016) }\end{array}$ \\
\hline & System Map & 17 & $\begin{array}{c}\text { (Beuren et al., 2010; Geum and Park, 2011; Costa } \\
\text { Junior., 2012; Lim et al., 2012; Bertoni et al., 2013; } \\
\text { Hoss, 2014; Amaral et al., 2017) }\end{array}$ \\
\hline & IDEFO & 13 & $\begin{array}{c}\text { (Durugbo et al., 2011; Ribeiro, 2011; Bertoni et al., } \\
\text { 2016; Trevisan and Brissaud, 2016) }\end{array}$ \\
\hline & Service CAD & 13 & $\begin{array}{c}\text { (Cavalieri and Pezzotta, 2012; Tran and Park, } \\
\text { 2014; Haber and Fargnoli, 2017) }\end{array}$ \\
\hline & SWOT Analysis & 12 & (Ribeiro, 2011; Costa Junior, 2012) \\
\hline & Storyboard & 10 & $\begin{array}{l}\text { (Ribeiro, 2011; Geum and Park, 2011; Costa } \\
\text { Junior, 2012; Hoss, 2014) }\end{array}$ \\
\hline & FMEA & 7 & $\begin{array}{l}\text { (Magnago, 2011; Cavalieri and Pezzotta, 2012; } \\
\text { Yoon et al., 2012; Haber and Fargnoli, 2017) }\end{array}$ \\
\hline
\end{tabular}


Table 3. Continued...

\begin{tabular}{|c|c|c|c|}
\hline Lifecycle Stage & Methods and tools & $\mathrm{n}^{\circ}$ Citations & References \\
\hline \multirow{7}{*}{ PSS Implementation } & QFD & 21 & (Kim et al., 2015) \\
\hline & Service Blueprint & 21 & (Ribeiro, 2011) \\
\hline & System Map & 17 & (Beuren et al., 2010; Amaral et al., 2017) \\
\hline & IDEFO & 13 & (Durugbo et al., 2011) \\
\hline & SWOT Analysis & 12 & (Durugbo et al., 2011) \\
\hline & Storyboard & 10 & (Hoss, 2014; Menezes, 2017) \\
\hline & FMEA & 7 & $\begin{array}{l}\text { (Magnago, 2011; Cavalieri and Pezzotta, 2012; } \\
\text { Yoon et al., 2012; Pezzotta et al., 2016) }\end{array}$ \\
\hline \multirow{5}{*}{ PSS Monitoring } & Service Blueprint & 21 & (Ribeiro, 2011) \\
\hline & IDEFO & 13 & $\begin{array}{c}\text { (Durugbo et al., 2011; Trevisan and Brissaud, } \\
\text { 2016) }\end{array}$ \\
\hline & SWOT Analysis & 12 & (Alvarenga Netto, 2015) \\
\hline & Storyboard & 10 & (Hoss, 2014; Fukushima, 2018) \\
\hline & FMEA & 7 & (Yoon et al., 2012; Pezzotta et al., 2016) \\
\hline \multirow{6}{*}{$\begin{array}{l}\text { PSS Destination } \\
\text { After Use }\end{array}$} & IDEFO & 13 & (Durugbo et al., 2011) \\
\hline & SWOT Analysis & 12 & (Alvarenga Netto, 2015) \\
\hline & Storyboard & 10 & (Hoss, 2014) \\
\hline & FMEA & 7 & (Pezzotta et al., 2016) \\
\hline & Reverse logistics & 7 & (Ribeiro, 2011) \\
\hline & Remanufacturing & 7 & $\begin{array}{l}\text { (Widera and Seliger, 2015; Anacleto, 2017; } \\
\text { Marques, 2018) }\end{array}$ \\
\hline
\end{tabular}

Source: Authors.

These methods and tools have been studied and used to develop the concept of a model for the development of PSS, presented in the following sections.

\section{Results and discussions from phase 2}

The model overview is presented in Figure 3. The PSS lifecycle phases are listed as A, B, C, D and E (see Table 1). FMEA is presented as a tool gate on F12, F21, F29, F34 and F38.

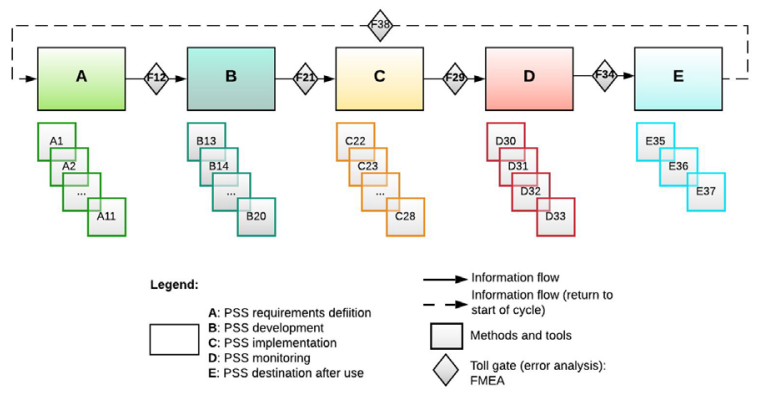

Figure 3. Overview of the feed-back model. Source: Authors.

The following sections show the feedback of the conceptual PSS development model, presented according to the phases of its lifecycle. Using the methods and tools in the sequence proposed by the model ensures the best performance of each step and greater assertiveness in the processes. 


\section{PSS Requirements Definition}

To start the development of a PSS by identifying consumer needs and transforming them into requirements, the feedback model for this life cycle stage (see Figure 4) provides a compilation of methods and tools capable of assisting the processes involved in PSS requirements definition.

\section{PSS REQUIRIMENTS DEFINITION}

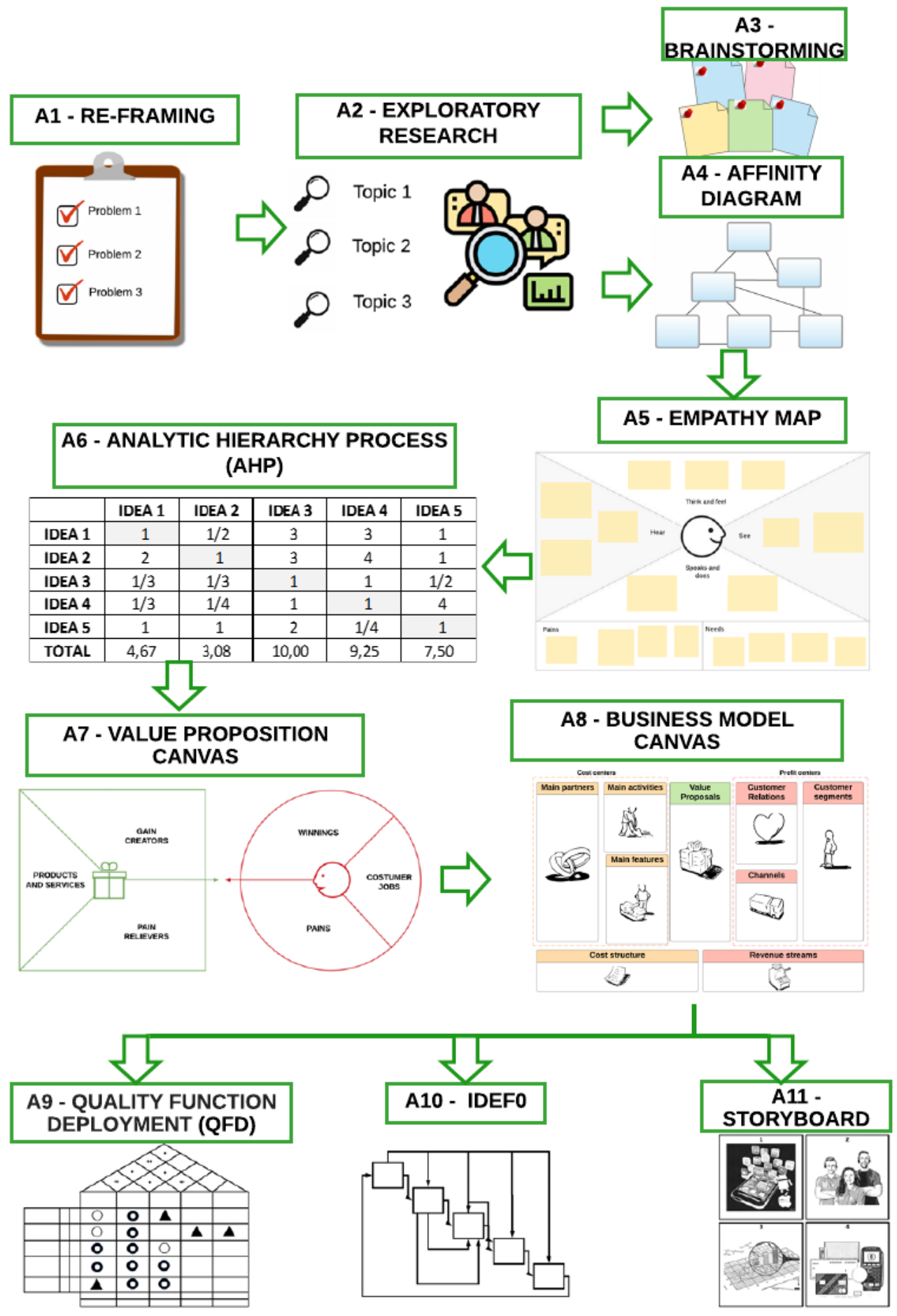

Figure 4. Retro-fed model for the PSS requirements definition step. 
For the survey of customer demands and needs, PSS specialists suggested the inclusion of Design Thinking methods and tools, capable of enhancing organizational innovation through deep customer understanding, user feedback testing and futuristic thinking (Joachim et al., 2020). Aiming at collecting information and planning studies, the tools of Design Thinking, Re-framing and Exploratory Research (Woloszyn et al., 2018) (methods and tools $A 1$ and A2, respectively, in Figure 4), were added to the conceptual model.

To assist in generating business ideas, Brainstorming and Affinity Diagram are presented in the model. Brainstorming (A3 method in Figure 4) was proposed in phase 1 of the research, presenting 11 citations in the literature suggesting its use. Thus, specialists' evaluations and reasonable results in the statistical analysis guaranteed the maintenance of these methods and tools in the feedback model.

Affinity Diagram (A4), as well as Re-framing and Exploratory Research methods, was added as a suggestion by specialists as a Design Thinking tool capable of assisting the ideation stage, problem solving and identification of client demands (Suzianti et al., 2020). Brainstorming and Affinity Diagram are presented as a choice option in the model. However, we suggest the application of both methods, since they complement each other (Suzianti et al., 2020).

Specialists highlighted the importance of understanding the business value proposition before departing to use tools such as Business Model Canvas. Thus, to broaden the understanding of customer needs, Empathy Map (Suzianti and Arrafah, 2019) (A5) was included. The Analytic Hierarchy Process (AHP) (A6) was added to the model for its efficiency in screening ideas during the innovation process (Huang et al., 2020), through a rational and comprehensive structure (Al-Dawalibi et al., 2020)

The inclusion of Value Proposition Canvas (A7) occurred due to specialists' suggestion. This tool establishes a connection between Empathy Map (A5) and the fields of Business Model Canvas (A8) (Gierej, 2017), and represents the products and services involved in the business proposal, aiming at generating significant results to meet customer's needs (Hajiheydari, 2019).

Business Model Canvas (A8) was proposed in phase 1 of the research, where fourteen researches suggested its application in PSS development. Satisfactory results in the statistical analysis, maintained the tool in the feedback model, offering a simple and effective graphic representation, capable of improving the organizational logic to create, offer and capture value (Scaramuzzi et al., 2020).

Specialists pointed out that some tools presented in phase 1 of the research have very similar characteristics related to the categorization and hierarchization of requirements, highlighting IDEF0 and QFD. In view of this, QFD (A9), IDEF0 (A10) and Storyboard (A11) were represented in the model allowing the selection of one option for application. These tools had already been presented in phase 1 of the survey, and given their satisfactory results in statistical analysis, their applications in this stage of the PSS life cycle were maintained.

Meanwhile, SWOT, Service Blueprint and FMEA were removed from the PSS requirements definition phase and transferred to other life cycle stages. PSS specialists suggested removing SWOT analysis and replacing Service Blueprint with Product-Service Blueprint. Finally, the model was fed back to the requirements definition stage of a PSS (Figure 4).

\section{PSS Development}

To assist in extracting information for the development of a PSS based on the requirements established in the previous life cycle phase, the model was fed back for the development stage (Figure 5). 


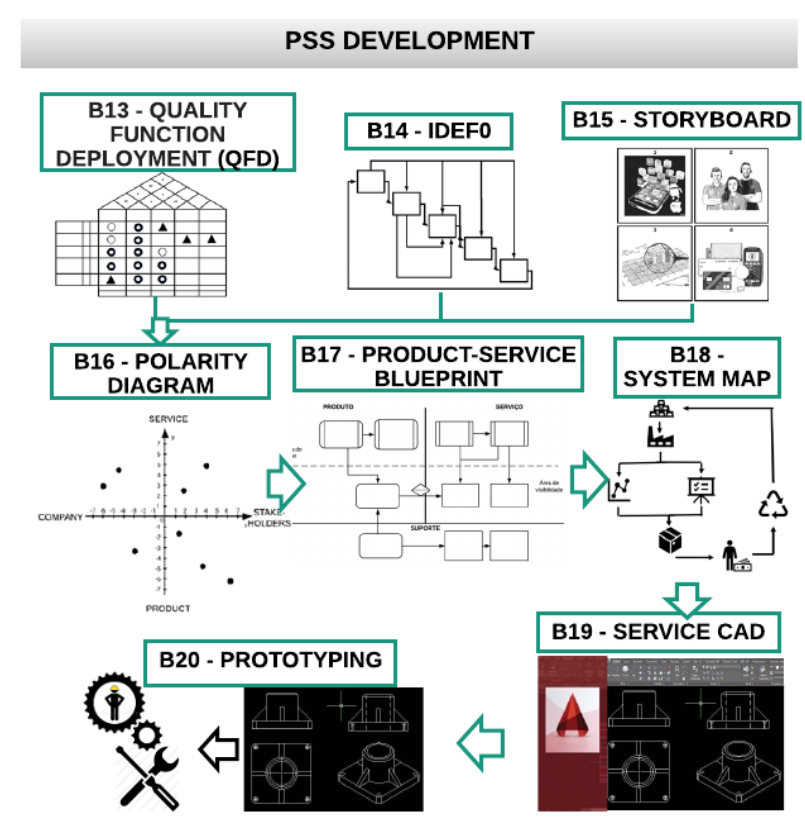

Figure 5. Retro-fed model for the PSS development step. Source: Authors.

In order to obtain information on the main processes involved in developing a PSS, QFD (tool B13 in Figure 5), IDEFO (B14) and Storyboard (B15) are initially proposed. As justified in the requirements definition step, these tools are presented as options due to the similarity in their contributions, as they can all model the processes of the development step, ensuring better understanding and improvements. These tools, presented in phase 1 of this research and with satisfactory results in the statistical analysis, were maintained in the feedback model.

PSS experts suggested the inclusion of methods and tools related to the degree of stakeholder involvement and capable of capturing value for the business proposal. Thus, the Polarity Diagram (B16) (Vezzoli, 2010) was included in the model, making it possible to analyze the involvement of stakeholders in the system (Bacchetti et al., 2016), guiding conceptualization and innovation at the systemic level (Costa Junior et al., 2010).

Service Blueprint was the tool best evaluated in the statistical analysis, presenting the largest mean and the smallest standard deviation in most stages of the PSS life cycle, representing convergence in the opinions of the respondents in the survey. However, Service Blueprint was suggested to be replaced by Product-Service Blueprint (B17) and used before System map tool. This is justified by the need to map the processes at this stage of the life cycle before defining partners and distribution flows for products and services.

Service Blueprint is intended for service design, and its application in PSS isn't recommended, as it fails to address some factors considered essential in developing a PSS (Yoon et al, 2012). Therefore, Geum and Park (2011) add new lines, areas and symbols to Service Blueprint and propose the use of Product-Service Blueprint, a systemic structure that represents the relationship between products and services, valuing sustainable consumption and production (Geum and Park, 2011).

In phase 1 of this research, System Map (B18) was already proposed, presenting 17 citations in the analyzed bibliography. As it obtained satisfactory results in the statistical analysis, corresponding to the variable with the lowest standard deviation (greater convergence in the specialists' responses), its use was maintained in the feedback model.

Although Service CAD (B19) obtained average results in statistical analysis, its use was maintained due to the suggestion of specialists to include prototyping (B20) to the retro-fed model. Service CAD generates virtual prototypes, capable of integrating design, modeling and optimization stages of the system (Arias-Rosales and Osorio-Gómez, 2020). 
The methods and tools removed in the feedback of the development stage were SWOT analysis, FMEA and Service Blueprint. Statistical analysis pointed SWOT analysis as the variable with the smallest average in the dimension.

As in the requirements definition step, the use of FMEA in PSS development was contested by some specialists. However, the factorial analysis pointed FMEA as the element that best explained the requirements definition and development dimensions of PSS, with variances of $39.0009 \%$ and $32.049 \%$, respectively. Given that FMEA can identify possible failures and develop measures considering aspects of products and services (Kimita et al., 2018), we decided to include it among the stages of the life cycle as a tool gate. The model was then fed back for the PSS development phase (Figure 5).

\section{PSS Implementation}

Methods and tools capable of assisting processes involved in implementing a PSS, such as identifying characteristics of how the PSS should be used by the consumer, are presented through the feedback model for the implementation phase of a PSS (Figure 6).

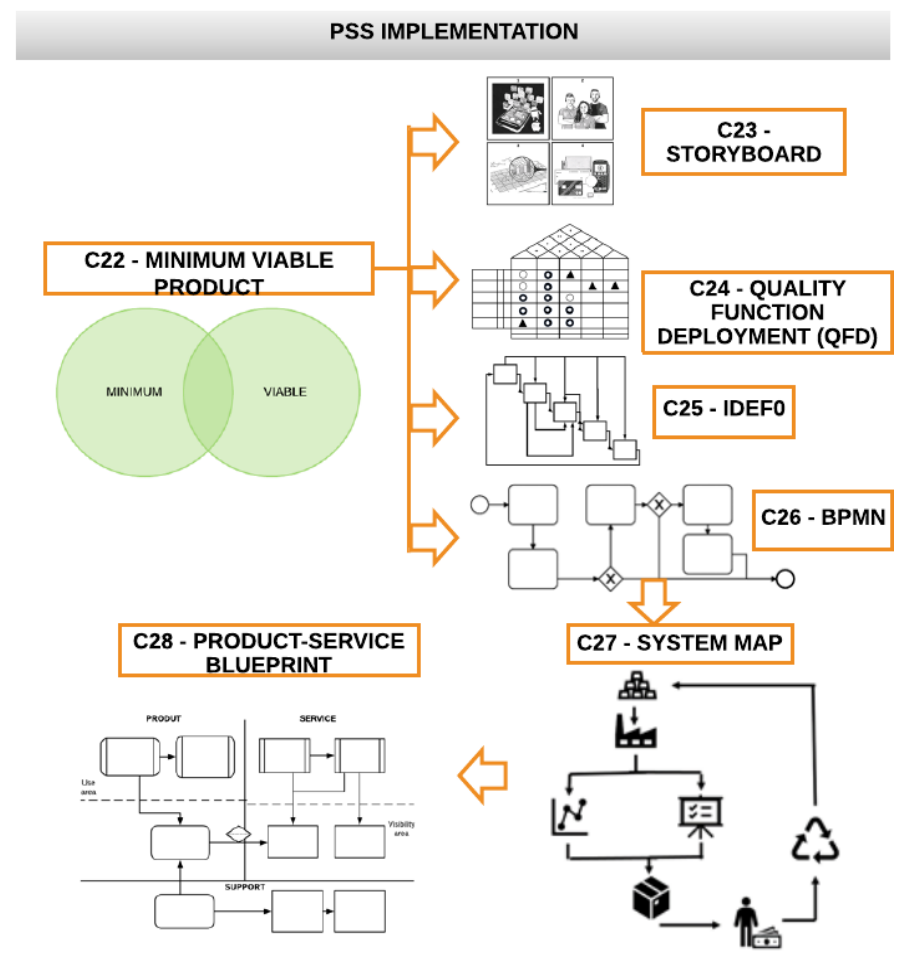

Figure 6. Retro-fed model for the PSS implementation step. Source: Authors.

Considering the information obtained from the application of the development methods and tools, the PSS is implemented. Specialists in PSS have pointed out the need to include methods or tools for experimentation in process optimization. Thus, the feedback model initially proposes the use of Minimum Viable Product (C22 in Figure 6), which is able to promote the implementation with sufficient resources only to meet the initial requirements of the customer, in order to generate feedback for the next stages of the life cycle (PerezVidal et al., 2019).

Storyboard (C23), QFD (C24), IDEF0 (C25) and BPMN (C26) are presented in the model as options for the selection of one. Storyboard, QFD and IDEFO had already been proposed in phase 1 of the model. As they obtained reasonable results in statistical analysis and weren't questioned by specialists, their application in the feedback model was maintained. BPMN tool was included in the model due to the suggestion of specialists to use project management 
approaches, and to its capability of describing behavior and interactions of interorganizational processes (Corradini et al., 2020).

System Map (C27) was the variable that obtained the greatest variance in factor analysis (51.42\%), corresponding to the tool that best explained PSS implementation. Thus, it was maintained in the feedback model, enabling coded and progressive representation of processes and actors, highlighting their interactions in the system (Sousa-Zomer and Cauchick Miguel, 2018).

Finally, the model proposes to use Product-Service Blueprint (C28), which presented the highest average for both requirements definition and development stages of a PSS lifecycle. The variable also obtained the lowest standard deviation, representing the highest level of agreement among the respondents. At this stage of the PSS lifecycle, Service Blueprint tool was also replaced by Product-Service Blueprint, which is more suitable for product-service systems.

As in the development phase of a PSS, the tools removed in the feedback of the deployment phase were SWOT analysis, FMEA and Service Blueprint. Thus, the model was feedback for the deployment phase of a PSS (Figure 6).

\section{PSS Monitoring}

Given the information obtained from the implementation phase, the methods and tools presented through feedback from the conceptual model to the monitoring phase of a PSS (Figure 7) offer support for making improvements to the system in order to continuously satisfy the consumer.

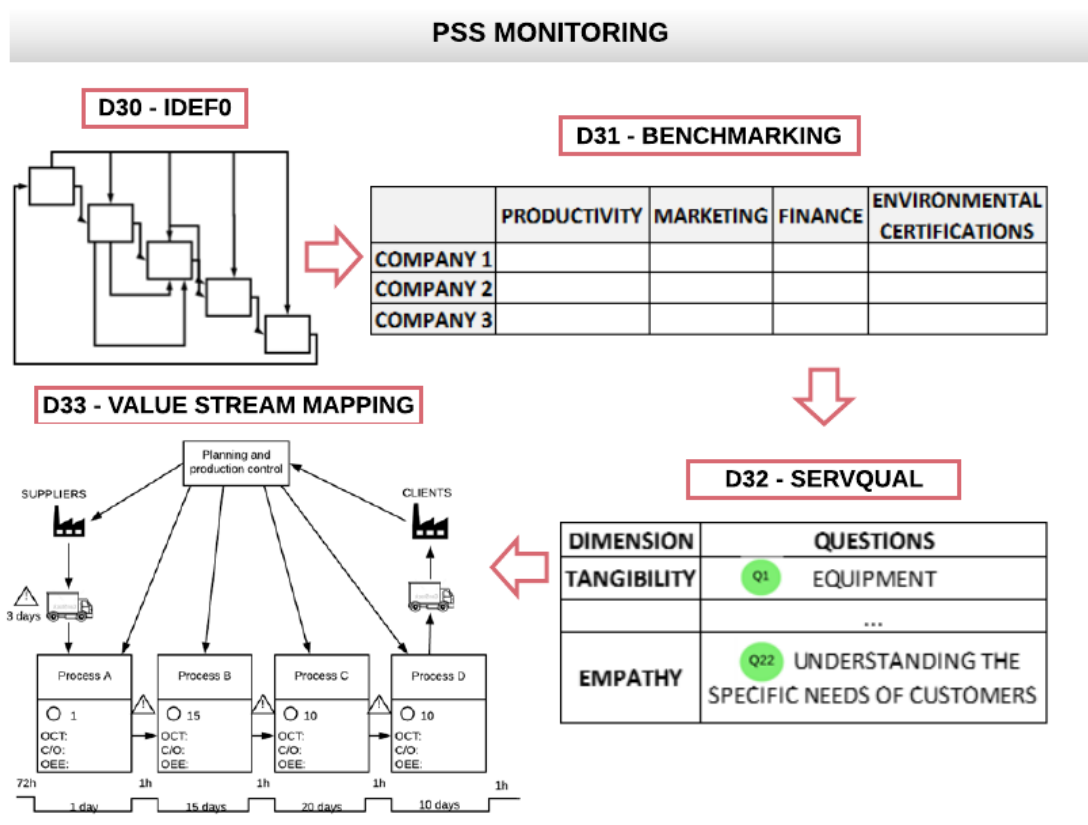

Figure 7. Retro-fed model for the PSS monitoring step.

Source: Authors.

At this stage, methods and tools aimed at identifying improvements in the system are proposed by the feedback model. Initially, IDEF0 is presented (D30 in Figure 7), capable of collecting information and monitoring the system (Ovchinkin et al., 2019). As it obtained satisfactory results in statistical analysis, its feasibility was maintained at this stage of the life cycle.

PSS experts suggested that specific methods and tools for the monitoring phase were included to optimize the processes. Benchmarking (D31) was thus included in the feedback 
model, given its ability to improve service delivery through comparative analysis with leading companies in the area (Reim et al., 2019).

SERVQUAL (D32) was added due to the specialists' suggestion to evaluate and monitor the quality of the services provided. Catulli (2012) proves the feasibility of SERVQUAL in increasing knowledge about PSS acceptability by consumers and Peitzika et al. (2020) conclude that it is highly reliable and valid for measuring consumer expectations regarding the quality of service provided.

Finally, the feedback model proposes the use of the Value Stream Mapping (D33), included due to the suggestion of the respondents in the survey. This tool provides an overview of the processes, indicating improvements (Morlock and Meier, 2015) and providing a framework for sustainable production processes (Soltani et al., 2020).

The methods and tools removed in the feedback phase of a PSS monitoring were: SWOT analysis, Storyboard, Service Blueprint and FMEA. The SWOT analysis variable was the one with the lowest variance in statistical analysis (factor analysis), corresponding to the tool considered less adequate to explain this dimension. The descriptive analysis of the statistical data pointed out that Storyboard variable was the one that presented the smallest mean of this dimension $(X=2.63)$, justifying its removal in the back-fed model.

Specialists contested the use of the same methods and tools for different stages of the PSS life cycle. In view of this, Service Blueprint wasn't included in the feedback model for the monitoring phase, nor was it replaced by Product-Service Blueprint as in the development and implementation phases of PSS but replaced by other specific tools to the monitoring phase. In this way, the model was fed back into the monitoring phase of a PSS (Figure 7).

\section{PSS Destination After Use}

To ensure the appropriate destination of all post-use situations of a PSS, the methods and tools proposed by the feedback model are presented in Figure 8.

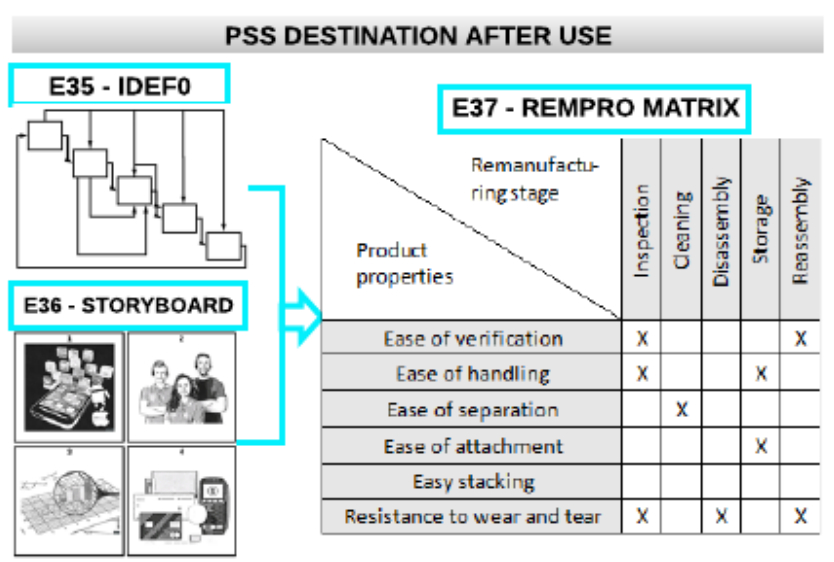

Figure 8. Retro-fed model for the PSS destination after use step.

Source: Authors.

The methods and tools proposed at this stage help allocate the components of a PSS appropriately, returning to the beginning of the lifecycle with information obtained at all stages. Initially, the feedback model proposes the use of IDEF0 (E35 in Figure 8) and Storyboard (E36). These tools had already been proposed in phase 1 of this research, and as they presented satisfactory results in the statistical analyses, (IDEF0 with the largest variance), its application in the post-use destination stage was maintained.

Specialists suggested the inclusion of strategies capable of enabling remanufacturing, repair, recycling and reconditioning processes. Therefore, RemPro Matrix (E37), proposed by 
Sundin (2004), was included in the retro-fed model in order to illustrate the relationship between each remanufacturing stage, highlighting the main properties of the product (Sundin, 2004).

The methods and tools removed in the feedback of the PSS destination after use step were: SWOT analysis, reverse logistics, remanufacturing and FMEA. In this dimension, SWOT analysis presented the lowest mean of all statistical analysis and the lowest variance, corresponding to the least adequate variable to explain the post-use destination, justifying its exclusion from the feedback model.

The specialists highlighted the need for end-of-life strategies (reverse logistics and remanufacturing) to be discussed and integrated in the early stages of the life cycle, from defining requirements for their effective functionality. The experts also emphasized that reverse logistics and remanufacturing are best referred to as an area of knowledge and an approach, respectively. As they do not have a specific structure to follow, their feasibility can be included in the methods and tools presented in the feedback model, considering their applications from the requirements definition stage of a PSS. The model has therefore been fed back to the post-use destination stage of a PSS (Figure 8).

\section{CONCLUSIONS}

The goal of this paper was to present a holistic perspective of methods and tools for the development of Product Service Systems. These methods and tools were gathered from literature and classified according to the PSS lifecycle - which proved to be relevant, as this action ensures greater structuring and control of business proposals, analyzing the processes from the definition of requirements to the destination after use of the PSS.

The step-to-step process presented in Figures 4-8 is an early concept of a model for PSS development. If followed in the proposed sequence, the steps can either lead up to a new PSS business proposition or to the optimization of an existent business. The presented methods and tools can be used to optimize processes and identify and correct possible failures in the PSS lifecycle.

The study follows a gap presented by Kim and Lee (2020), presenting a model that is faces a holistic approach for product-service systems. It differs from other proposals (e.g. Geum and Park, 2011; Lim et al., 2012) mainly for this perspective, considering the whole lifecycle of a PSS and not focusing only in one sphere (e.g. sustainability).

In order to extend the access to the model, it is necessary to develop it in a more practical way. We propose that, in future studies, a systematization is carried out, programmed in such a way that the client provides information of the proposal to receive a general feedback of the business, allowing analyses of viability, strengths and weaknesses, opportunities for improvement, among others.

However, to carry out the systematization, future studies may focus on new applications in cases to make sure the model is feasible before departing to the systematization. To this end, such research can apply the model to different types of PSS, in order to analyze its scope and conceptual contribution. Thus, this research can be considered an initial study for the elaboration and systematization of a model, capable of guiding and optimizing the development of Product-Service Systems, thus generating greater assertiveness to business proposals.

\section{REFERENCES}

Al-Dawalibi, A., Al-Dali, I.H. and Alkhayyal, B.A. (2020), "Best marketing strategy selection using fractional factorial design with analytic hierarchy process", MethodsX, Vol. 7. http://dx.doi.org/10.1016/j.mex.2020.100927.

Alvarenga Netto, C.A. (2015), "Viabilidade da servitização em comércio popular: o caso Pop Centro Topbox", in Anais do XXXV ENEGEP, ABEPRO, Rio de Janeiro. 
Amaral, M., Santos, F.A.F., Pereira, D. et al. (2017), 'Proposta de um Sistema Produto-Serviço para embalagens de proteção de produtos', in Anais do XXXVII ENEGEP, ABEPRO, Rio de Janeiro.

Anacleto, C.A. (2017), A Ênfase ao Consumidor na Avaliação da Qualidade nos Sistemas Produto-serviço: Aplicação ao Setor de Telecomunicações. Tese de doutorado, Universidade Federal de Santa Catarina, Florianópolis.

Arias-Rosales, A. and Osorio-Gómez, G. (2020), "Albatros Create: an interactive and generative tool for the design and 3D modeling of wind turbines with wavy leading edge", International Journal on Interactive Design and Manufacturing, Vol. 14, No. 2, pp. 631-50. http://dx.doi.org/10.1007/s12008-020-00655-y.

Aurich, J.C., Fuchs, C. and Wagenknecht, C. (2006), "Life cycle oriented design of technical Product-Service Systems", Journal of Cleaner Production, Vol. 14, No. 17, pp. 1480-94. http://dx.doi.org/10.1016/j.jclepro.2006.01.019.

Bacchetti, E., Vezzoli, C. and Landoni, P. (2016), "Sustainable Product-Service System (S.PSS) applied to Distributed Renewable Energy (DRE) in Low and Middle-income Contexts: A Case Studies Analysis", Procedia CIRP, Vol. 47, pp. 442-7. http://dx.doi.org/10.1016/j.procir.2016.03.085.

Baines, T.S., Lightfoot, H.W., Evans, S. et al. (2007), "State-of-the-art in product-service systems", Proceedings of the Institution of Mechanical Engineers. Part B, Journal of Engineering Manufacture, Vol. 221, No. 10, pp. 1543-52. http://dx.doi.org/10.1243/09544054JEM858.

Baldassarre, B., Keskin, D., Diehl, J.C. et al. (2020), "Implementing sustainable design theory in business practice: a call to action", Journal of Cleaner Production, Vol. 273, pp. 123113. http://dx.doi.org/10.1016/j.jclepro.2020.123113.

Bertoni, A., Bertoni, M. and Isaksson, O. (2013), "Value visualization in Product Service Systems preliminary design", Journal of Cleaner Production, Vol. 53, pp. 103-17. http://dx.doi.org/10.1016/j.jclepro.2013.04.012.

Bertoni, A., Bertoni, M., Panarotto, M. et al. (2016), "Value-driven product service systems development: methods and industrial applications", CIRP Journal of Manufacturing Science and Technology", CIRP, Vol. 15, pp. 42-55. http://dx.doi.org/10.1016/j.cirpj.2016.04.008.

Beuren, F.H. (2011), Principais fatores críticos de sucesso para sistemas produto-serviço. Master thesis, Federal University of Santa Catarina.

Beuren, F.H., Gomes Ferreira, M.G. and Cauchick Miguel, P.A. (2013), "Product-service systems: a literature review on integrated products and services", Journal of Cleaner Production, Vol. 47, pp. 222-31. http://dx.doi.org/10.1016/j.jclepro.2012.12.028.

Beuren, F.H., Sousa-Zomer, T.T. and Cauchick-Miguel, P.A. (2017), "Proposal of a framework for productservice systems characterization", Produção, Vol. 27. http://dx.doi.org/10.1590/0103-6513.20170052.

Beuren, F.H., Tolfo, C., Ferreira, M.G.G. et al. (2010), “Uma proposta de modelagem e gestão de processos de negócio de sistemas produto serviço", in Anais do XXX ENEGEP, ABEPRO, Rio de Janeiro.

Bonilla-Alicea, R.J., Watson, B.C., Shen, Z. et al. (2020), "Life cycle assessment to quantify the impact of technology improvements in bike-sharing systems", Journal of Industrial Ecology, Vol. 24, No. 1, pp. 138-48. http://dx.doi.org/10.1111/jiec.12860.

Catulli, M. (2012), "What uncertainty? Further insight into why consumers might be distrustful of product service systems", Journal of Manufacturing Technology Management, Vol. 23, No. 6, pp. 780-93. http://dx.doi.org/10.1108/17410381211253335.

Cavalieri, S. and Pezzotta, G. (2012), "Product-Service Systems Engineering: state of the art and research challenges", Computers in Industry, Vol. 63, No. 4, pp. 278-88. http://dx.doi.org/10.1016/j.compind.2012.02.006.

Chadegani, A.A., Salehi, H., Yunus, M.M. et al. (2013), "A comparison between two main academic literature collections: Web of Science and scopus databases", Asian Social Science, Vol. 9, No. 5, pp. 18-26. http://dx.doi.org/10.5539/ass.v9n5p18.

Chandra, E., Liu, S., Sfenrianto, S. et al. (2019), "Analysis of the effect of security and trust on buying decision on the tokopedia mobile apps", in 4th ICITISEE: International Conference on Information Technology, Information Systems and Electrical Engineering, IEEE, USA, pp. 452-456. http://dx.doi.org/10.1109/ICITISEE48480.2019.9003846.

Chen, K.S. and Yu, C.M. (2020), "Fuzzy test model for performance evaluation matrix of service operating systems", Computers \& Industrial Engineering, Vol. 140, pp. 106240. http://dx.doi.org/10.1016/j.cie.2019.106240. 
Corradini, F., Morrichetta, A., Polini, A. et al. (2020), "Correctness checking for BPMN collaborations with sub-processes", Journal of Systems and Software, Vol. 166, pp. 110594. http://dx.doi.org/10.1016/j.jss.2020.110594.

Coşkun, Ö.K., Yağcı, İ., Göçmen, S. et al. (2019), "Validity and reliability of the Turkish version of "cardiac rehabilitation barriers scale", Gülhane Tip Dergisi, Vol. 61, No. 2, pp. 59-63. http://dx.doi.org/10.26657/gulhane.00055.

Costa Junior, J. (2012), Proposição de um Modelo de Referência para o Design de Serviços Ecoeficientes em Sistemas Produto-Serviço. Dissertação de Mestrado em Design, Universidade Federal do Paraná, Curitiba.

Costa Junior, J., Pereira, J.V.I., Zacar, C.H. et al. (2010), "Sistema Produto+Serviço para o cozinhar sustentável: estudo de Caso Projeto Monno", Projetica, Vol. 1, No. 1, pp. 162. http://dx.doi.org/10.5433/2236-2207.2010v1n1p162.

Durán, R.J. and Condorí, M.Á. (2019), "Deprivation Index for Small Areas Based on Census Data in Argentina", Social Indicators Research, Vol. 141, No. 1, pp. 331-63. http://dx.doi.org/10.1007/s11205017-1827-6.

Durugbo, C., Tiwari, A. and Alcock, J.R. (2011), "A review of information flow diagrammatic models for product-service systems", International Journal of Advanced Manufacturing Technology, Vol. 52, No. 912, pp. 1193-208. http://dx.doi.org/10.1007/s00170-010-2765-5.

Fadheel, W., Abusharkh, M. and Abdel-Qader, I. (2018) 'On feature selection for the prediction of phishing websites', in Proceedings of the 15th International Conference on Dependable, Autonomic and Secure Computing, IEEE, USA, pp. 871-876. http://dx.doi.org/10.1109/DASC-PICom-DataComCyberSciTec.2017.146.

França, C.L., Broman, G., Robèrt, K.-H. et al. (2017), "An approach to business model innovation and design for strategic sustainable development", Journal of Cleaner Production, Vol. 140, pp. 155-66. http://dx.doi.org/10.1016/j.jclepro.2016.06.124.

Frederiksen, T.B., Pieroni, M.P.P., Pigosso, D.C.A. et al. (2021), "Strategic development of product-service systems (Pss) through archetype assessment", Sustainability (Switzerland), Vol. 13, No. 5, pp. 1-22. http://dx.doi.org/10.3390/su13052592.

Fukushima, N. (2018), Identificação de Oportunidades de Inovação em Serviços para Empresas de Manufatura: Protocolo com Abordagem Abdutiva por Meio do Design. Tese de Doutorado em Design, Universidade Federal do Paraná, Curitiba.

Geum, Y. and Park, Y. (2011), "Designing the sustainable product-service integration: A product-service blueprint approach", Journal of Cleaner Production, Vol. 19, No. 14, pp. 1601-14. http://dx.doi.org/10.1016/j.jclepro.2011.05.017.

Gierej, S. (2017), "Techniques for designing value propositions applicable to the concept of outcomeeconomy", Engineering Management in Production and Services, Vol. 9, No. 1, pp. 56-63. http://dx.doi.org/10.1515/emj-2017-0006.

Goedkoop, M.J., van Halen, C.J.G., te Riele, H.R.M. et al. (1999), 'Product Service systems, Ecological and Economic Basics', Dutch Ministries of Environment (VROM) and Economic Affairs, pp. 1-118.

Guan, H., Alix, T. and Bourrières, J.P. (2017), "Reference product-service system lifecycle models in virtual enterprise context", Procedia CIRP, Vol. 64, pp. 387-92. http://dx.doi.org/10.1016/j.procir.2017.03.022.

Haber, N. and Fargnoli, M. (2017), "Design for product-service systems: a procedure to enhance functional integration of product-service offerings", International Journal of Product Development, Vol. 22, No. 2, pp. 135-64. http://dx.doi.org/10.1504/IJPD.2017.086474.

Hajiheydari, N. (2019), 'IoT big data value map : how to generate value from loT data', in 5th International Conference, ACM, pp. 98-103. https://doi.org/10.1145/3312714.3312728.

Hoss, M.J. (2014), Prototipagem de Serviços: um Estudo Exploratório com Foco na Iluminação de Habitações de Interesse Social, Dissertação de Mestrado em Design, Universidade Federal do Paraná, Curitiba.

Huang, Z., Ahmed, C. and Mickael, G. (2020), "A model for supporting the ideas screening during front end of the innovation process based on combination of methods of EcaTRIZ, AHP, and SWOT", Concurrent Engineering, Research and Applications. http://dx.doi.org/10.1177/1063293X20911165.

Joachim, G., Schulenkorf, N., Schlenker, K. et al. (2020), "Design thinking and sport for development: enhancing organizational innovation", Managing Sport and Leisure, Vol. 25, No. 3, pp. 175-202. http://dx.doi.org/10.1080/23750472.2019.1611471. 
Jorge, G.G. (2017), "A Contribuição da Hierarquia de Concerns para o Processo de Projeto de Sistema Produtoserviço. Dissertação de Mestrado em Design, Universidade do Vale do Rio dos Sinos, Porto Alegre.

Karabagias, I.K., Karabournioti, S., Karabagias, V.K. et al. (2020), "Palynological, physico-chemical and bioactivity parameters determination, of a less common Greek honeydew honey: "dryomelo", Food Control, Vol. 109. http://dx.doi.org/10.1016/j.foodcont.2019.106940.

Kim, S., Son, C., Yoon, B., et al. (2015), "Development of an Innovation Model Based on a Service-Oriented Product Service System (PSS)", Sustainability (Switzerland), Vol. 7, No. 11, pp. 14427-49. http://dx.doi.org/10.3390/su71114427.

Kim, Y.S. and Lee, H. (2020), "Process characteristics of Product-Service Systems development: comparison of seven manufacturing company cases", Journal of Cleaner Production, Vol. 286, pp. 124971. http://dx.doi.org/10.1016/j.jclepro.2020.124971.

Kimita, K., Sakao, T. and Shimomura, Y. (2018), "A failure analysis method for designing highly reliable product-service systems", Research in Engineering Design, Vol. 29, No. 2, pp. 143-60. http://dx.doi.org/10.1007/s00163-017-0261-8.

Labbate, R., Silva, R.F., Rampasso, I.S. et al. (2021), "Business models towards SDGs: the barriers for operationalizing Product-Service System (PSS) in Brazil", International Journal of Sustainable Development and World Ecology, Vol. 28, No. 4, pp. 350-9. http://dx.doi.org/10.1080/13504509.2020.1823517.

Lim, C.-H., Kim, K.J., Hong, Y.-S. et al. (2012), "PSS Board: a structured tool for product-service system process visualization", Journal of Cleaner Production, Vol. 37, pp. 42-53. http://dx.doi.org/10.1016/j.jclepro.2012.06.006.

Magnago, P.F. (2011), Combinação produto-serviço: uma análise de suas consequências na gestão do processo de desenvolvimento de produtos. Dissertação de Mestrado em Engenharia de Produção, Universidade Federal do Rio Grande do Sul, Porto Alegre.

Marques, C.A.N. (2018), Framework para Definir Modelos de Processos Específicos de Desenvolvimento de PSS. Tese de doutorado, Universidade de São Paulo.

Matsas, M., Pintzos, G., Kapnia, A. et al. (2017), "An Integrated Collaborative Platform for managing Product-service Across their Life Cycle", Procedia CIRP, Vol. 59, pp. 220-6. http://dx.doi.org/10.1016/j.procir.2016.09.009.

Mazo, S.Z. (2012), Incorporação da Voz do Cliente nas Etapas Iniciais do Desenvolvimento de Sistemas Produtoserviço (PSS). Dissertação de Mestrado em Engenharia Mecânica e de Materiais, Universidade Tecnológica Federal do Paraná, Curitiba.

Menezes, J.P.F. (2017), Dinâmicas de Capital Social Relacionadas ao Desenvolvimento de um Sistema Produto Serviço Sustentável, Dissertação de Mestrado em Design, Universidade Federal de Pernambuco, Recife.

Mont, O.K. (2002), "Clarifying the concept of product-service system", Journal of Cleaner Production, Vol. 10, pp. 237-45. http://dx.doi.org/10.1109/ACIIDS.2009.18.

Morelli, N. (2006), "Developing new product service systems (PSS): methodologies and operational tools", Journal of Cleaner Production, Vol. 14, No. 17, pp. 1495-501. http://dx.doi.org/10.1016/j.jclepro.2006.01.023.

Morelli, N. (2009), "Service as value co-production: reframing the service design process", Journal of Manufacturing Technology Management, Vol. 20, No. 5, pp. 568-90. http://dx.doi.org/10.1108/17410380910960993.

Morlock, F. and Meier, H. (2015), "service value stream mapping in industrial product-service system performance management", Procedia CIRP, Vol. 30, pp. 457-61. http://dx.doi.org/10.1016/j.procir.2015.02.128.

Oliva, R. and Kallenberg, R. (2003), "Managing the transition from products to services", International Journal of Service Industry Management, Vol. 14, No. 2, pp. 160-72. http://dx.doi.org/10.1108/09564230310474138.

Ovchinkin, O.V., Pykhtin, A.I. and Shirokova, L.V. (2019), "Monitoring system of graduate employment as a factor of improving the efficiency of university educational activities", International Journal of Emerging Trends in Engineering Research, Vol. 7, No. 12, pp. 849-53. 
Peitzika, E., Chatzi, S. and Kissa, D. (2020), "Service Quality Expectations in the Fitness Center Context: A Validation of the Expectations Component of the SERVQUAL Scale in Greece", Services Marketing Quarterly, Vol. 41, No. 2, pp. 89-104. http://dx.doi.org/10.1080/15332969.2020.1742977.

Perez-Vidal, C., Gracia, L., Sanchez-Caballero, S. et al. (2019), "Design of a polishing tool for collaborative robotics using minimum viable product approach", International Journal of Computer Integrated Manufacturing, Vol. 32, No. 9, pp. 848-57. http://dx.doi.org/10.1080/0951192X.2019.1637026.

Pezzotta, G., Pirola, F., Pinto, R. et al. (2015), "A Service Engineering framework to design and assess an integrated product-service", Mechatronics, Vol. 31, pp. 169-79. http://dx.doi.org/10.1016/j.mechatronics.2015.05.010.

Pezzotta, G. Pirola, F., Rondini, A. et al. (2016), "Towards a methodology to engineer industrial productservice system - Evidence from power and automation industry", CIRP Journal of Manufacturing Science and Technology, Vol. 15, pp. 19-32. http://dx.doi.org/10.1016/j.cirpj.2016.04.006.

Reim, W., Parida, V. and Örtqvist, D. (2015), "Product-Service Systems (PSS) business models and tactics A systematic literature review", Journal of Cleaner Production, Vol. 97, pp. 61-75. http://dx.doi.org/10.1016/j.jclepro.2014.07.003.

Reim, W., Sjödin, D.R. and Parida, V. (2019), "Servitization of global service network actors - A contingency framework for matching challenges and strategies in service transition", Journal of Business Research, Vol. 104, pp. 461-71. http://dx.doi.org/10.1016/j.jbusres.2019.01.032.

Ribeiro, V.C. (2011), Aplicação do conceito Sistema Produto-Serviço (PSS) no desenvolvimento integrado de produto. Dissertação de Mestrado em Engenharia Mecânica e de Materiais, Universidade Tecnológica Federal do Paraná, Curitiba, PR.

Rozenfeld, H., Forcellini, F. A., Amaral, D. C., Toledo, J. C., Silva, S. L., Alliprandini, D. H., Scalice, R. K. (2006), Gestão de Desenvolvimento de Produtos: uma referência para a melhoria do processo. Saraiva, São Paulo.

Sakao, T., Hara, T. and Fukushima, R. (2020), "'Using product/service-system family design for efficient customization with lean principles: Model, method, and tool'", Sustainability (Switzerland), Vol. 12, No. 14, pp. 1-25. http://dx.doi.org/10.3390/su12145779.

Scaramuzzi, S., Belletti, G. and Biagioni, P. (2020), "Integrated Supply Chain Projects and multifunctional local development: the creation of a Perfume Valley in Tuscany", Agricultural and Food Economics, Vol. 8, No. 1. http://dx.doi.org/10.1186/s40100-019-0150-8.

Soltani, M., Aouag, H. and Mouss, M.D. (2020), "An integrated framework using VSM, AHP and TOPSIS for simplifying the sustainability improvement process in a complex manufacturing process", Journal of Engineering, Design and Technology, Vol. 18, No. 1, pp. 211-29. http://dx.doi.org/10.1108/JEDT-09-20180166.

Sousa-Zomer, T.T. and Cauchick Miguel, P.A. (2018), "Sustainable business models as an innovation strategy in the water sector: An empirical investigation of a sustainable product-service system", Journal of Cleaner Production, Vol. 171, pp. S119-29. http://dx.doi.org/10.1016/j.jclepro.2016.07.063.

Sundin, E. (2004), "Product and process design for successful remanufacturing", Science And Technology, 960.

Suzianti, A. and Arrafah, G. (2019), "User interface redesign of dental clinic ERP system using design thinking: a case study", in Proceedings of the 5th International Conference of Industrial and Business Engineering, Association for Computing Machinery, New York, pp. 193-197.

Suzianti, A., Wulandari, A.D., Yusuf, A.H. et al. (2020), “Design thinking approach for mobile application design of disaster mitigation management", in ACM International Conference Proceeding Series, ACM, pp. 29-33. http://dx.doi.org/10.1145/3379310.3379324.

Tokarz, B., Tokarz, B., Fagundes, A.B. et al. (2020), "Product-service systems: a literature review on assisting development", International Journal of Advanced Engineering Research and Science, Vol. 7, No. 6, pp. 41-51. http://dx.doi.org/10.22161/ijaers.76.5.

Tran, T. and Park, J.Y. (2014), "Development of integrated design methodology for various types of product - service systems", Journal of Computational Design and Engineering, Vol. 1, No. 1, pp. 37-47. http://dx.doi.org/10.7315/JCDE.2014.004.

Tran, T. and Park, J.Y. (2016a), "Development of a novel co-creative framework for redesigning product service systems", Sustainability, Vol. 8, No. 5, pp. 434. http://dx.doi.org/10.3390/su8050434. 
Tran, T. and Park, J.Y. (2016b), "Development of a novel set of criteria to select methodology for designing product service systems", Journal of Computational Design and Engineering, Vol. 3, No. 2, pp. 112-20. http://dx.doi.org/10.1016/j.jcde.2015.10.001.

Trevisan, L. and Brissaud, D. (2016), "Engineering models to support product-service system integrated design", CIRP Journal of Manufacturing Science and Technology, Vol. 15, pp. 3-18. http://dx.doi.org/10.1016/j.cirpj.2016.02.004.

Tukker, A. (2004), "Eight types of product-service system: Eight ways to sustainability? Experiences from suspronet", Business Strategy and the Environment, Vol. 13, No. 4, pp. 246-60. http://dx.doi.org/10.1002/bse.414.

Tukker, A. (2015), "Product services for a resource-efficient and circular economy - a review", Journal of Cleaner Production, Vol. 97, pp. 76-91. http://dx.doi.org/10.1016/j.jclepro.2013.11.049.

van der Laan, A.Z. and Aurisicchio, M. (2020), "A framework to use product-service systems as plans to produce closed-loop resource fl ows", Journal of Cleaner Production, Vol. 252, pp. 119733. http://dx.doi.org/10.1016/j.jclepro.2019.119733.

Vandermerwe, S. and Rada, J. (1988), "Servitization of business: adding value by adding services", European Management Journal, Vol. 6, No. 4, pp. 314-24. http://dx.doi.org/10.1097/JOM.0b013e318161786f.

Vezzoli, C. (2010), Design de Sistemas para a Sustentabilidade, EDUFBA, Salvador.

Widera, H. and Seliger, G. (2015) 'Methodology for exploiting potentials of remanufacturing by reducing complexity for original equipment manufacturers', CIRP Annals - Manufacturing Technology, Vol. 64, No. 1, pp. 463-466. http://dx.doi.org/10.1016/j.cirp.2015.04.111.

Woloszyn, M., Dick, M.E., Gonçalvez, B.S. et al. (2018), "Design thinking no contexto do projeto editorial: contribuições instrumentais", DAPesquisa, Vol. 13, No. 21, pp. 59-75. http://dx.doi.org/10.5965/1808312913212018059.

Yaduvanshi, R., Bansal, S. and Kumar, A. (2019), "Factors affecting traffic management using two step cluster", International Journal of Engineering and Advanced Technology, Vol. 9, No. 1, pp. 1184-9. http://dx.doi.org/10.35940/ijeat.A9516.109119.

Yoon, B., Kim, S. and Rhee, J. (2012), "An evaluation method for designing a new product-service system", Expert Systems with Applications, Vol. 39, No. 3, pp. 3100-8. http://dx.doi.org/10.1016/j.eswa.2011.08.173.

Zhang, L., Zhang, J., Duan, Z-y et al. (2015), "Sustainable bike-sharing systems: characteristics and commonalities across cases in urban China", Journal of Cleaner Production, Vol. 97, pp. 124-33. http://dx.doi.org/10.1016/j.jclepro.2014.04.006.

Zupic, I. and Čater, T. (2015), "Bibliometric methods in management and organization", Organizational Research Methods, Vol. 18, No. 3, pp. 429-72. http://dx.doi.org/10.1177/1094428114562629.

Author contributions: All authors contributed equally to this article. 